THE ACADEMIC PROFESSION 



\title{
THE ACADEMIC PROFESSION
}

\author{
National, Disciplinary, \\ and Institutional Settings
}

\author{
Edited by \\ BURTON R. CLARK
}

University of CALIFornia PRESS

Berkeley Los Angeles London 
University of California Press

Berkeley and Los Angeles, California

University of California Press, Ltd.

London, England

Copyright (C) 1987 by The Regents of the University of California

\section{Library of Congress Cataloging in Publication Data}

The Academic profession.

Based on papers presented at an international conference held at the Villa Serbelloni, Bellagio, Italy, in 1984, and sponsored by the Rockefeller Foundation.

Includes bibliographies and index.

1. College teachers-Congresses. 2. Universities and colleges-FacultyCongresses. I. Clark, Burton R. II. Rockefeller Foundation.

LB2331.7.A23 $1987 \quad 378^{\prime} .12 \quad 86-30916$

ISBN 0-520-05940-9 (alk. paper)

Printed in the United States of America 